\begin{tabular}{|l|l|l||}
\hline \multicolumn{2}{|c|}{ PublisherInfo } \\
\hline \hline PublisherName & $:$ & BioMed Central \\
\hline \hline PublisherLocation & $:$ & London \\
\hline \hline PublisherImprintName & $:$ & BioMed Central \\
\hline \hline
\end{tabular}

\title{
Improving adenovirus vaccines
}

\begin{tabular}{|l|l|l||}
\hline \multicolumn{2}{|c|}{ ArticleInfo } \\
\hline \hline ArticleID & $:$ & 5076 \\
\hline \hline ArticleDOI & $:$ & $10.1186 /$ gb-spotlight-20050405-01 \\
\hline \hline ArticleCitationID & $:$ & spotlight-20050405-01 \\
\hline \hline ArticleSequenceNumber & $:$ & 52 \\
\hline \hline ArticleCategory & $:$ & Research news \\
\hline ArticleFirstPage & $:$ & 1 \\
\hline \hline ArticleLastPage & $:$ & 3 \\
\hline \hline & & RegistrationDate : 2005-4-5 \\
\hline ArticleHistory & $:$ & OnlineDate \\
\hline \hline ArticleCopyright & $:$ & BioMed Central Ltd2005-4-5 \\
\hline \hline ArticleGrants & $:$ & \\
\hline \hline ArticleContext & $:$ & 130596611 \\
\hline \hline
\end{tabular}


Researchers have created a successful vaccine strategy in mice that uses the immune system's typical antibody response to adenoviruses - which can prevent modified viruses from expressing their payloads and thus diminish the vaccine's efficacy - to actually boost the antibody response to the vaccine, they report in the current issue of the Journal of Clinical Investigation.

By attaching 720 copies of an immunogenic polypeptide from Pseudomonas aeruginosa to the capsid shell of a replication-deficient adenovirus in addition to inserting the DNA into the virus, scientists at Weill Medical College of Cornell University in New York were able to successfully vaccinate mice against the bacterium. The strategy, they said, could be useful for other vaccines that don't need the cellbased immunity that arises from expression.

"It's a dual Trojan horse," said study coauthor Ron Crystal, whose earlier work helped pioneer the use of adenovirus for gene transfer.

When DNA for an epitope from the pathogen is inserted into the viral genome in typical adenovirus vaccines, antigen-presenting cells such as dendritic cells are stimulated into a cellular immune response by the expression of that DNA. An adenovirus vaccine for HIV, for example, has been developed by Merck and entered phase II trials in January.

One problem with using adenovirus for gene transfer is that "you not only get immunity against the gene that you put in, but you get immunity against the capsid of the adenovirus," Crystal said. As a result, expression of transgenes inserted into the viral DNA is shut down within a week or two, and subsequent administration of the same serotype of virus doesn't boost the response. Moreover, adenovirus capsid proteins, especially the hexone that covers most of the surface, act as potent adjuvants, spurring the immune response into high gear.

In the current study, "we're taking advantage of the immunogenicity" of the capsid by building it out of a modified hexone protein that also displays the epitope, Crystal told The Scientist. The researchers chose epitopes from extracellular loops of the Pseudomonas outer membrane protein F, OprF, finding the strongest immune response from a 14-amino-acid segment called Epi8. Prior workhad shown that these epitopes are highly conserved and elicit a strong antibody response.

After administering their doubly-modified virus, the researchers detected a cellular immune response to OprF, which varied with the haplotype of the mice. When exposed to a pulmonary infection with $P$. aeruginos $a$, most of the mice that had been treated with the vaccine survived, whereas all untreated mice died within a few days. In addition, a second dose of the virus 2 weeks later gave the desired boost in the antibody reaction to OprF. In contrast, the second dose did not increase in the response to a betagalactosidase, DNA for which had been included in the virus.

John Staczek and his colleagues from Louisiana State University had also used other viruses as vectors to express Epi8 as a vaccine for Pseudomonas, which causes acute lung infections that are especially dangerous for people with cystic fibrosis. "But the adenovirus-based vectors have already been tried in humans," Staczek said, calling the new work "a natural combination." 
"What is so clever about this approach is that they exploited the anti-capsid response [that is usually a problem]," James Wilson, of the University of Pennsylvania, told The Scientist via E-mail. The modest doses needed for a vaccine and method of administration should avoid the serious problems that occurred in some adenovirus gene therapy trials, such as that of Jesse Gelsinger, the 18-year-old who died in 1999 during a trial run by Wilson that required high doses of adenovirus.

\section{References}

1. S Worgall et al., "Protection against $P$. aeruginosa with an adenovirus vector containing an OprF epitope in the capsid," J Clin Invest, DOI:10.1172/JCI200523135, April 1, 2005., [http://www.jci.org/ cgi/reprint/JCI200523135v1.pdf]

2. Ronald G. Crystal, [http://www.med.cornell.edu/research/ronaldcrystal/]

3. "Merck's investigational HIV/AIDS vaccine candidate advances to phase ii efficacy testing in collaborative clinical trial," Merck press release, Janaury 24, 2005., [http://www.merck.com/newsroom/ press_releases/research_and_development/2005_0124.html]

4. H.E. Gilleland, Jr., et al., "Use of synthetic peptides to identify surface-exposed, linear B-cell epitopes within outer membrane protein F of Pseudomonas aeruginosa," Curr Microbiol, 31:279-86, November 1995.

5. John Staczek, [http://www.sh.lsuhsc.edu/microbiology/staczek.html]

6. H.E Gilleland, Jr., et al., "Chimeric animal and plant viruses expressing epitopes of outer membrane protein $\mathrm{F}$ as a combined vaccine against Pseudomonas aeruginosa lung infection" FEMS Immunol Med Microbiol,27:291-7, April 2000.

7. James M. Wilson, [http://www.med.upenn.edu/camb/faculty/gt/wilson.html]

8. H. Black, "Wilson leaves UPenn's gene therapy institute," The Scientist, April 23, 2002. [http://www.the-scientist.com/news/20020423/03] 